\title{
Human Metapneumovirus and Its Role in Childhood Respiratory Infections
}

\author{
Arne Simon · Catherine Manoha $\cdot$ Andreas Müller • \\ Oliver Schildgen
}

Published online: 16 May 2014

(C) Springer Science + Business Media New York 2014

\begin{abstract}
The human metapneumovirus has acquired the attention of the scientific community because it has been shown to be one of the most important viral pathogens in respiratory tract infections. Since its discovery in 2001, it has rapidly been shown that the virus infects all age groups, but the major burden is observed in pediatric patients. In this review, we focus on the clinical features of the human metapneumovirus, its epidemiology, antiviral therapy of HMPV infections and future treatment options.
\end{abstract}

Keywords Human metapneumovirus - HMPV ·

Respiratory tract disease

\section{Introduction}

Since its discovery in 2001, the human metapneumovirus [1•] has been the subject of many clinical and laboratory studies. It has been identified as a serious pathogen in

\section{A. Simon}

Klinik für Pädiatrische Onkologie und Hämatologie,

Universitätsklinikum des Saarlandes, Homburg/Saar, Germany

C. Manoha

Laboratoire de Serologie-Virologie, CHU-Dijon, Dijon, France

\section{A. Müller}

Zentrum für Kinderheilkunde, Universitätsklinikum Bonn, Abteilung für Neonatologie, Bonn, Germany

O. Schildgen ( $\square)$

Kliniken der Stadt Köln gGmbH, Krankenhaus Merheim, Institut für Pathologie, Klinikum der Privaten Universität Witten/ Herdecke, Ostmerheimer Str. 200, 51109 Köln (Cologne), Germany

e-mail: schildgeno@kliniken-koeln.de human airway infection and besides immunosuppressed and elderly patients mainly affects children.

The majority of childhood infections occur in the upper and lower respiratory tract. The route of infection is similar to the transmission of other paramyxoviruses such as parainfluenza viruses $1-4$ and the respiratory syncytial virus.

\section{Epidemiology}

hMPV was first identified in 2001 as a new causative agent of RTIs in children and was then detected worldwide [1•]. The exclusive natural reservoir of hMPV is human. The virus probably spreads in the same way as RSV, from person to person, generally via the transmission of large respiratory droplets or by direct contact with respiratory secretions [2]. Both viruses are relatively labile in the environment and sensitive to drying [3]. Their transmission is particularly effective in close-living populations. Household contact between hMPV-positive children might lead to more frequent illness and more frequent absences from work or school than that between RSV-positive children [4]. The nosocomial impact of hMPV is estimated to be as high as that for RSV $[5,6]$.

Information about incubation periods is poorly referenced, but they are estimated to be 4-9 days for both RSV and hMPV [5, 7]. Viral shedding in infants lasts 2-3 weeks. The duration of virus excretion appears to correlate with the severity of infection [8]. hMPV viral RNA was detected for a median of 5 days against 11 days for RSV in infected children [9]. Both viruses can be detected for several weeks after infection in immunocompromised patients [10,11].

Epidemics are community acquired. They are annual and seasonal in temperate climates. They occur mainly 
during winter and at the beginning of spring, and are slightly offset in time compared with RSV epidemics. hMPV infections can be detected throughout the year in particular in warm climates [12]. hMPV isolates have been classified by phylogenetic analysis into two major groups, $\mathrm{A}$ and $\mathrm{B}$, which are subdivided into four subgroups, A1, A2, B1 and B2. hMPV diverged from avian metapneumovirus $C$ around 200-250 years ago, while the genetic diversity of the lineages and sublineages occurred recently, $30-50$ years ago $[13,14]$. The A1 lineage was detected mostly up to 2003 and has rarely been detected since 2004 [15-17•]. Lineages could be replaced over time with newly emerging variants. Lineages co-circulate each year independently of the location, usually with one alternating as dominant every 1-3 years [18]. Their periodic emergence is due in part to geographic and climatic factors and preexisting immunity $[19,20]$. Seasonal traveling of populations may also play a role. Reinfections of humans with genetically distinct hMPV strains are possible [21•, 22]. The F protein is the major target of neutralization [23]. In animal studies, the conserved $F$ protein mediates crossprotection, whereas infection by different lineages leads only to limited cross-protection [16, 23-25]. The antigenic variation of the $\mathrm{G}$ and $\mathrm{SH}$ proteins may explain this weak cross-protection and the dominance of heterologous lineages during subsequent epidemics in human populations. Unlike the RSV G protein, the hMPV G protein is not a major target of neutralization [23]. Whether a given hMPV lineage is associated with disease severity is unclear $[4,15$, 26-28].

hMPV infections are observed in all age groups, with a high prevalence in pediatric patients. Primary infection occurs early in childhood. In children, the first hMPV infection appears to take place at 6 months of life, after which reinfections may occur. High seroprevalence rates are reached at 5-10 years of age compared with 2 years of age for RSV [1・, 22, 29, 30]. Two large population-based prospective surveillance studies of hMPV infection were conducted in the US among children less than 5 years old who were hospitalized with ARI or fever [31, 32]. Williams et al. reported that 42 of 1,104 (3.8\%) children tested positive for hMPV. hMPV infection was shown to be associated with a substantial burden of hospitalizations and outpatient visits among children throughout the first 5 years of life. During this age period, hMPV was detected in about $6 \%$ of hospitalized children, $7 \%$ of those seen in outpatient clinics and $7 \%$ of those examined in emergency departments [31]. The estimated annual burden of outpatient visits associated with hMPV infection was 55 clinic visits and 13 emergency department visits per 1,000 attending children. The age range of the most hospitalized infants was less than 6 months of age $(3$ per 1,000). Children hospitalized with hMPV infection were more likely to receive a diagnosis of pneumonia or asthma, to require supplemental oxygen and to have a longer stay in the intensive care unit than those hospitalized without hMPV infection. Premature birth and asthma were more frequent among hospitalized children with hMPV infection than among those without hMPV infection. Children hospitalized with hMPV infection are older than those with RSV infection [33]. The risk of hospitalization is greater in younger subjects though older children are also at risk of developing severe hMPV infection [34, 35]. Female gender, hospital acquisition of human metapneumovirus infection, prematurity and the presence of chronic medical conditions have been found to be risk factors for severe hMPV infection and to increases mortality due to hMPV infection in children $[34,35]$. Chronic lung disease, congenital heart disease, neuromuscular disorders and trisomy 21 are the underlying medical conditions most frequently associated with severe hMPV infection [31, 32, 34-36]. Case reports of fatal or persistant hMPV infections have been reported in immunocompromised children suggesting that host's immune response may also play a key role in disease pathogenesis $[10,37]$. A recent retrospective study in children with cancer reports that hMPV may result in significant disease but is usually not fatal [38].

\section{Diagnosis}

\section{Cell Culture}

Primary isolation is mainly done in either LLC-MK2 cells or Vero cells, and the addition of exogenous trypsin is needed for virus propagation. The cytopathic effect varies; some strains induce the formation of syncytia or cause focal rounding and cell destruction $[1 \bullet, 39 \bullet$. However, the growth of hMPV in cell culture is too slow to be commonly used for diagnostic purposes. Primary isolation often requires several passages before any cytopathic effect becomes visible. Sensitivity of the cell culture has been shown to reach $82 \%$ compared with the real-time RT-PCR method when specimens are collected within 3 days after the onset of symptoms, but sensitivity decreased considerably thereafter $(\leq 50 \%)[40]$.

\section{Fluorescent-Antibody Staining}

Indirect Immunofluorescence detection of hMPV was first developed in in-house assays with a sensitivity $\geq 73 \%$ compared with PCR [41-43]. The use of cytospinenhanced slides provides slightly higher sensitivity [44]. All require a well-trained staff. Fluorescent-antibody staining assay kits then became commercially available. The detection of viral antigens is now mainly based on 
either direct immunofluoresence assay with monoclonal antibodies, as proposed by Chemicon/Millipore (Billerica, MA), or with cytospin-assisted direct immunofluorescence assay (DFA), as proposed by Diagnostics Hybrids (Athens, $\mathrm{OH})[45,46]$. This company has developed a simple DFA metapneumovirus identification kit and a format that allows the identification of eight different viruses, including hMPV. This commercial direct fluorescent-antibody assay allows the rapid detection of hMPV antigens from clinical samples with $>95 \%$ sensitivity compared with those obtained with RT-PCR [47].

\section{Rapid Immunochromatographic Tests}

These could become an interesting approach as they can be used at the bedside, although they have low sensitivity. So far, however, rapid diagnostic tests are restricted to the detection of influenza virus and respiratory syncytial virus (RSV).

\section{Serological Tests}

The measurement of seroconversion to diagnose hMPV infection is of limited value as a rapid diagnosis is necessary, and serological tests tend to be reserved for epidemiological studies.

\section{RT-PCR}

The reverse-transcription PCR (RT-PCR) is most commonly used for hMPV diagnosis. Many home-brew RTPCR-based assays have been developed for the detection of hMPV in clinical samples; they usually detect all hMPV genotypes, but sometimes with different sensitivities. They are often based on conserved regions within the $\mathrm{N}$ gene or the F gene. Non-specific symptoms associated with respiratory infections, overlapping seasons of respiratory viruses and co-infections have orientated detection demands toward multiplexing. Large cohorts of patients coinfected with two or more pathogens have recently been evaluated using multiplex assays [48-50]. Commercially available RT-PCR multiplex kits are now available from numerous diagnostic companies to detect at least hMPV and RSV [51, 52•]. While the ResPlex II by Qiagen and MultiCodePLx by EraGen Biosciences (USA) offer a broader virus detection range and are easy to use, the xTAG PRV by Luminex (Canada) showed increased sensitivity to common viral targets represented in the assays. The RespFinder19 is able to detect 19 pathogens simultaneously, including 15 respiratory viruses. It was shown to have high sensitivity (98.2\%) and specificity (100\%) for hMPV [53]. The RespiFinder assay and the Seeplex RV15 ACE assay (Seegene, Korea) [54, 55] are more sensitive than cell culture and comparable to singleplex real-time RT-
PCR. A recent study compared six commercialized multiplex PCR kits for the diagnosis of respiratory infections [56]. The overall sensitivity for hMPV was above $75 \%$ for all these kits, but below $75 \%$ for some other viruses or bacteria. The overall specificity was excellent (>94\%) for all pathogens. The spectrum of tested agents, the hands-on time and the time to obtain complete results $(2 \mathrm{~h} 30 \mathrm{~min}$ to 9 h) can be key factors in the selection of a kit. Multiplex PCR can be used to detect coinfections and has improved our understanding of the roles of various viral agents in acute respiratory disease. Multiplex RT-PCR is increasingly being used to diagnose respiratory infections and has proved to be more sensitive than viral culture and antigen detection. However, Multiplexassays are expensive with estimated costs between 40 and $80 €$ per sample (list prices) versus 5-15 € for a singleplex PCR.

Rapid and accurate diagnosis of viral respiratory infections is crucial to improve the management of patients and reduce unnecessary exposure to antibiotics. PCR assays are generally more sensitive than other methods. However, immunofluorescence or DFA staining of cells from nasopharyngeal secretions (IF) offers advantages as a first-line test and produce a more rapid result in emergency cases or when PCRs are done at most once a day.

\section{Clinical Features}

HMPV has been identified as a prominent viral respiratory tract pathogen that causes remarkable morbidity in early childhood, in particular in infants and toddlers with a median age of 6-12 months in hospitalized children [31, 57, 58]. The most common clinical disease manifestations are cough, fever/chills, rhinorrhea and bronchitis, bronchiolitis [59, 60]. Up to $30 \%$ of all HMPV-infected inpatients complain of otalgia [34]. Upper respiratory tract infection with HMPV infection may cause or at least pave the way for acute otitis media $[61,62]$. In a recent study, there was no difference in viral load in children with hMPV-positive upper respiratory tract infection with or without acute otitis media complications [63]. HMPV has only rarely been identified as etiologic agent in children with viral croup [64]. Distinguishing features of HMPV and the respiratory syncytial virus (RSV), to which HMPV is second as a cause of bronchiolitis in infants, have recently been excellently reviewed by Papenburg and Bovin [65]. HMPV can cause LTRI as severe as in RSV-infected children [66, 67•].

Whether HMPV infection can directly involve the central nervous system in terms of encephalitis is still debated [68, 69]. Papenburg et al. detected convulsions in 3 of 62 HMPV-infected hospitalized children (4.8\%) [34], but these events may merely represent febrile seizures in children with genetic susceptibility. In a recently published case series, 
nine cases of CNS illness temporally associated with the presence of HMPV nucleic acid in the upper airway are described; all children included in this latter study with HMPV infections and seizures were hospitalized and three were intubated because of status epilepticus. Neither HMPV RNA nor antihMPV-specific IgM was detectable in the CSF from the five patients for whom CSF was available [70].

In infants and children with severe HMPV infection, respiratory symptoms are accompanied by diarrhea and vomiting in up to $40 \%$. Fever $>39^{\circ} \mathrm{C}$, tachypnea, retractions, nasal flaring, tachycardia, feeding difficulties and oxygen saturation below $90 \%$ (pulse oximetry) are red flags indicating severe LRTI in infants. In premature infants, HMPV infection may cause apnea-bradycardiasyndrome. The hospitalization rate in otherwise healthy children has been determined as $2 \%$ [71]. Risk factors for a complicated course (higher risk of pneumonia, a need for supplemental oxygen and hospitalization) resemble those of other respiratory viruses, in particular of respiratory syncytial virus [34]. Premature infants (gestational age $<32$ weeks, birth weight $<1,500 \mathrm{~g}$, with or without chronic lung disease of prematurity) [72, 73], infants and toddlers with hemodynamically relevant congenital heart disease [74] and children with severe combined immunodeficiency or immunocompromised patients $[75,76]$ face an increased risk. Age $<6$ months and having a crowded home $(\geq 3$ children in the same household) increase the risk of HMPFrelated hospitalization [34, 65]. Children and adults with asthma [77, 78] or cystic fibrosis [79, 80], and adults with chronic obstructive pulmonary disease [81] may experience acute pulmonary exacerbations due to HMPV infection. Although this population has not been addressed in detail, children with severe neuromuscular impairment or Down's syndrome (trisomy 21) face an increased risk of a complicated course in any viral LRTI, including HMPV [82]. The rate of HMPV-infected children with severe clinical courses requiring pediatric intensive care is low, and the attributable mortality due to HMPV infection is even much lower $(<0.1 \%)$ [31, 71]. Fatal outcomes have been described mainly in children and adults with severe comorbidities such as cancer, stem cell transplantation or solid organ transplantation [10, 38, 83-87].

On the other hand, not all infants and children admitted to a PICU because of a severe HMPV LRTI display preexisting comorbidities or risk factors. Gupta et al. [88] reported the case of a 32-month-old boy with a previous history of asthma who developed respiratory failure 2 weeks after onset of cough and rhinorrhea and required extracorporeal membrane oxygenation (ECMO) for 9 days after failing highfrequency oscillatory ventilation (HFOV). This case and other reports from children treated in pediatric intensive care units confirm that HMPV causes severe and even lifethreatening LRTI in children of all ages [35, 36, 74, 89].
HMPV is capable of surviving and remaining contagious on hands, hand contact surfaces, medical instruments and fomites [3]. In this regard, HMPC can easily be transmitted from patient-to-patient in in- and outpatient health care facilities. Hand disinfection before and after any patient contact, droplet and contact precautions are necessary to avoid nosocomial infection of other patients and of health care workers. Extended outbreaks of HMPV infection even with case fatalities have been described in nursing homes for the elderly [90-92].

To distinguish viral and bacterial LRTIs is difficult on clinical and laboratory grounds (leukocyte counts, C-reactive protein). In patients with acute HMPV infection high viral loads have been detected in respiratory specimens [93-96]. Without any attempt to identify the causative pathogen, many attending physicians decide to administer antibiotics to febrile children with HMPV LRTI $[66,97]$ or with asthma exacerbation due to HMPV infection [98, 99]. This common practice represents a misuse of antibiotics and fosters the selection of resistant bacteria. Confirming this statement, HMPV positivity has not been associated with the rate of positive bacterial cultures of the blood or urine in inpatients in the landmark epidemiological study of Edwards et al. [31].

Surprisingly, although much is know about sequelae of RSV infections such as bronchospasm and subsequent childhood asthma, little is known about late effects of HMPV infections. So far, no long-term associations have been identified, probably because of different immune reactions. However, HMPV can also cause acute exacerbations of such chronic diseases and is more frequently associated with severe disease in adults and the elderly.

\section{Therapy}

No specific treatment evaluated in prospective controlled clinical trials in humans is available for human metapneumovirus. However, in the nucleoside analog ribavirin with known therapeutic effectivenes against respiratory syncytial virus (RSV), in vitro antiviral activity has been shown for hMPV as well. Studies using cell culture and a mouse model of ribavirin showed significantly decreased hMPV replication in rhesus monkey kidney epithelial cells (LLC-MK2 cells) and in the lungs of BALB/c mice after inoculation of ribavirin intraperitoneally $[100,101]$.

However, only small case series and observational studies have described the therapeutic use of ribavirin for treatment of hMPV infection, often in severely immunocompromised patients following solid organ transplantation or hematological disorders [102-104]. Recently, a retrospective study evaluated the effect of oral ribavirin on clinical outcomes of paramyxovirus infections including 
RSV, parainfluenza virus (PIV) and hMPV in adult patients with various hematological diseases [105]. A total of 145 patients were analyzed with $114(78 \%)$ in the ribavirin group and $31(21 \%)$ in the nonribavirin group. Although there were more patients with severe underlying disease and fewer additional treatments with intravenous immunoglobulin (IVIG) in the nonribavirin group, the analysis revealed no significant differences concerning 30-day mortality and the underlying respiratory death rate. Therefore, the authors concluded that ribavirin treatment does not improve the outcome in patients with hematologic diseases and infection with paramyxovirus. Nevertheless, it seems to be unclear whether these data should be transferred in hMPV-infected children. Case reports and small case series in pediatric and adult patients with hMPV infection mostly combined ribavirin with IVIG or corticosteroids, but the reports about treatment success are inconsistent. Whereas Dokos et al. found no effect of ribavirin combined with IVIG and corticosteroids in a 10-year-old girl with chronic graft-versus-host disease following allogenic HSCT [86], in a child with lymphoblastic leukemia and two children with Burkitt lymphoma, other case reports showed an effective treatment of hMPV pneumonia with combined administration of oral or i.v. ribavirin and IVIG [86, 102, 103, 106, 107]. The rationale for co-administration of IVIG has been motivated by in vitro studies that likewise found antiviral activity against hMPV in cell culture for ribavirin [100].

New therapeutic candidates such as fusion inhibitors, small interfering RNAs (siRNAs) and monoclonal antibodies are under development. The inhibition of the fusion of the viral and host cell membrane may be feasible by peptides, e.g., heptad repeat A (HRA) and B (HRB) interacting with the hMPV fusion protein, and they have been shown to be effective in hMPV-infected BALB/c mice [108]. Furthermore, siRNA has been shown to inhibit the hMPV virus replication in a murine model by targeting by nucleoprotein or phosphoprotein messenger RNA (mRNA) [109, 110].

Recently, a human anti-hMPV Fab DS7 antibody neutralized human metapneumovirus in vitro and in vivo (cotton rats) and may have prophylactic or therapeutic potential against severe human metapneumovirus infection, but clinical trials are still lacking [111]. Other monoclonal antibodies (e.g., MAb338, MPE8) generated against hMPV $\mathrm{F}$ protein or pre-fusion $\mathrm{F}$ protein have been shown to inhibit replication of hMPV in animal models, but clinical trials in human hMPV infection have not been conducted [107, 112-115]. This applies for vaccines, too; various vaccine candidates (e.g., live attenuated vaccines, subunit vaccines, virus-like particle vaccines) were tested for immunization of experimental animals and induce protective neutralizing antibodies, but clinical trials in human are lacking [116-120].
In conclusion, data on experimental usage of antiviral agents against hMPV in vitro and in vivo that should inhibit the replication of hMPV are ambivalent and variably promising, and even the development of specific vaccines has not been as successful as suspected yet. Despite the lack of significant clinical studies, ribavirin and IVIG seem to be the only therapeutic option, especially in immunocompromised children, but no general recommendation can currently be made [121].

\section{Severe Extrapulmonary Infections}

Although HMPV is clearly a respiratory pathogen, several case reports and case series have been published showing that by chance rare neurological symptoms can occur. The first description of neurological symptoms associated with an HMPV infection was the case of a toddler who died from encephalitis [122]. In this patient, HMPV RNA was detected in both the lung and the brain tissue, thus providing strong evidence of a causal relationship. Following this first report, further cases were published: In 2009, Arnold and coworkers described nine cases identified in the California Encephalitis Project cohort that suffered from encephalitis likely associated with human metapneumovirus infection [70]. In addition, Fernandez and colleagues found HMPV in the cerebrospinal fluid of a 10-year-old girl suffering from an acute encephalitis [123]. It is worth noting that a most recent study has identified an association of status epilepticus with HMPV infection [124]. In this latter study, two cases of toddlers with this clinical condition were described and were positive for HMPV. However, further systematic studies are lacking but required, as this would reduce the diagnostic gap of clinical cases with viral infection of the central nervous system but without the detection of a pathogen.

\section{Treatment Lessons Learned from Animal Models and In Vitro Analyses}

Although human metapneumovirus has been known for more than a decade, so far no specific therapies in the form of antiviral drugs are available for treatment of severe infections. A number of small animal models have been developed so far, including mice, cotton rats, hamsters, guinea pigs, ferrets and non-human primates such as African green monkeys and macaques [24, 125]. However, therapy studies are limited and have been performed in small rodents exclusively. Thereby, the Mus musculus strain $\mathrm{BALB} / \mathrm{c}$ has become the main model as it turned out to be the most robust model [126-129]. In this mouse model it was shown that ribavirin can reduce the 
replication of HMPV in vivo in the lung of infected animals by up to $5 \log 10$ and in concert with glucocorticoids can significantly reduce the global pulmonary inflammation [101]. This observation confirms earlier in vitro data from LLC-MK2 cells infected with HMPV and treated with ribavirin in which ribavirin displayed an antiviral acitivity (mean EC50 of $74 \pm 35 \mu \mathrm{M}$ ) similar to the inhibition of RSV replication [100]. It is therefore likely that a similar effect could also be observed in patients infected with HMPV. A similar effect could be reached by administering NMSO3, although this displayed an antiviral effect against HMPV in vitro but has been not tested yet in vivo [130]. A novel approach, not yet followed by many groups, could be the development of specific meroditerpenoids, which were originally isolated from marine algae and have shown an antiviral effect against HMPV in infected LLC-MK2 cells [131].

However, the most promising approach so far is the development of potent siRNAs that target viral RNA and thus may inhibit the viral replication. In 2008, the group of Gyu Boivin identified siRNAs that targeted the replication complex and a putative fusion inhibitor [108, 110]. The same target region of the siRNA was identified independently by our group and further tested in vivo [109]. We thereby not only demonstrated that the siRNA is active in vitro and in vivo but is also well tolerated, reaches the respiratory tract although no optimized siRNA delivery tool was used and showed that the siRNA cleaves the viral RNA in vivo. A further approach from an Australian group also confirmed that siRNA targeting of HMPV is a promising arm of antiviral therapy [132].

\section{Conclusions}

Despite the fact that symptomatic treatment of HMPV infections is successful and can be supported by off-label treatment with ribavirin, specific therapies are still not available. Unfortunately, efforts to further develop promising siRNAs for their use in vivo are limited because of the lack of public funding or commercial interests from the pharmaceutical industry.

HMPV has been shown to be a serious pathogen in childhood respiratory infections, but also in other patient groups, and thus requires the same attention as RSV or parainfluenza viruses, not least because it is a virus occurring worldwide.

Disclosure Arne Simon, Catherine Manoha, Andreas Müller and Oliver Schildgen declare that they have no conflict of interest.

Human and Animal Rights and Informed Consent This article does not contain any studies with human or animal subjects performed by any of the authors.

\section{References}

Papers of particular interest, published recently, have been highlighted as:

- Of importance

1. • van den Hoogen BG, de Jong JC, Groen J, Kuiken T, de Groot R, Fouchier RA, et al. A newly discovered human pneumovirus isolated from young children with respiratory tract disease. Nat Med. 2001;7(6):719-24. The initial description of humane metapneumovirus.

2. Hall CB, Douglas RG Jr. Modes of transmission of respiratory syncytial virus. J Pediatr. 1981;99(1):100-3.

3. Muller A, Tillmann RL, Simon A, Schildgen O. Stability of human metapneumovirus and human coronavirus NL63 on medical instruments and in the patient environment. J Hosp Infect. 2008;69(4):406-8.

4. Bosis S, Esposito S, Niesters HG, Crovari P, Osterhaus AD, Principi N. Impact of human metapneumovirus in childhood: comparison with respiratory syncytial virus and influenza viruses. J Med Virol. 2005;75(1):101-4.

5. Kim S, Sung H, Im HJ, Hong SJ, Kim MN. Molecular epidemiological investigation of a nosocomial outbreak of human metapneumovirus infection in a pediatric hemato-oncology patient population. J Clin Microbiol. 2009;47(4):1221-4.

6. Lee I, Barton TD. Viral respiratory tract infections in transplant patients: epidemiology, recognition and management. Drugs. 2007;67(10):1411-27.

7. Lessler J, Reich NG, Brookmeyer R, Perl TM, Nelson KE, Cummings DA. Incubation periods of acute respiratory viral infections: a systematic review. Lancet Infect Dis. 2009;9(5):291-300.

8. Sarasini A, Percivalle E, Rovida F, Campanini G, Genini E, Torsellini M, et al. Detection and pathogenicity of human metapneumovirus respiratory infection in pediatric Italian patients during a winter-spring season. J Clin Virol. 2006;35(1):59-68.

9. von Linstow ML, Eugen-Olsen J, Koch A, Winther TN, Westh $\mathrm{H}$, Hogh B. Excretion patterns of human metapneumovirus and respiratory syncytial virus among young children. Eur J Med Res. 2006;11(8):329-35.

10. Abed Y, Boivin G. Human metapneumovirus infection in immunocompromised child. Emerg Infect Dis. 2008;14(5):854-6.

11. Boeckh $\mathrm{M}$. The challenge of respiratory virus infections in hematopoietic cell transplant recipients. Br J Haematol. 2008;143(4):455-67.

12. Oliveira DB, Durigon EL, Carvalho AC, Leal AL, Souza TS, Thomazelli LM, et al. Epidemiology and genetic variability of human metapneumovirus during a 4-year-long study in Southeastern Brazil. J Med Virol. 2009;81(5):915-21.

13. Herfst S, de Graaf M, Schrauwen EJ, Sprong L, Hussain K, van den Hoogen BG, et al. Generation of temperature-sensitive human metapneumovirus strains that provide protective immunity in hamsters. J Gen Virol. 2008;89(Pt 7):1553-62.

14. Yang CF, Wang CK, Tollefson SJ, Piyaratna R, Lintao LD, Chu $\mathrm{M}$, et al. Genetic diversity and evolution of human metapneumovirus fusion protein over twenty years. Virol J. 2009;6:138.

15. Pitoiset C, Darniot M, Huet F, Aho SL, Pothier P, Manoha C. Human metapneumovirus genotypes and severity of disease in young children $(\mathrm{n}=100)$ during a 7-year study in Dijon hospital. France J Med Virol. 2010;82(10):1782-9.

16. van den Hoogen BG, Herfst S, Sprong L, Cane PA, Forleo-Neto E, de Swart RL, et al. Antigenic and genetic variability of human metapneumoviruses. Emerg Infect Dis. 2004;10(4):658-66.

17. - Williams JV, Wang CK, Yang CF, Tollefson SJ, House FS, Heck JM, et al. The role of human metapneumovirus in upper respiratory tract infections in children: a 20 -year experience. 
J Infect Dis. 2006;193(3):387-95. Important study that cover two retrospectively analysed decades of HMPV infections.

18. Narayanan H, Sankar S, Simoes EA, Nandagopal B, Sridharan G. Analysis of sequence diversity of human metapneumovirus collected from young children with acute respiratory tract infections in South India. Mol Diagn Therapy. 2013;17(4): 247-55.

19. Wang Y, Chen Z, Yan YD, Guo H, Chu C, Liu J, et al. Seasonal distribution and epidemiological characteristics of human metapneumovirus infections in pediatric inpatients in Southeast China. Arch Virol. 2013;158(2):417-24.

20. Welliver R. The relationship of meteorological conditions to the epidemic activity of respiratory syncytial virus. Paediatr Respir Rev. 2009;10(Suppl 1):6-8.

21. - Ebihara T, Endo R, Ishiguro N, Nakayama T, Sawada H, Kikuta $\mathrm{H}$. Early reinfection with human metapneumovirus in an infant. J Clin Microbiol. 2004;42(12):5944-6. Important report that show that reinfections are likely and that no long lasting immunity occurs.

22. Pavlin JA, Hickey AC, Ulbrandt N, Chan YP, Endy TP, Boukhvalova MS, et al. Human metapneumovirus reinfection among children in Thailand determined by ELISA using purified soluble fusion protein. J Infect Dis. 2008;198(6):836-42.

23. Skiadopoulos MH, Biacchesi S, Buchholz UJ, Amaro-Carambot E, Surman SR, Collins PL, et al. Individual contributions of the human metapneumovirus F, G, and SH surface glycoproteins to the induction of neutralizing antibodies and protective immunity. Virology. 2006;345(2):492-501.

24. MacPhail M, Schickli JH, Tang RS, Kaur J, Robinson C, Fouchier RA, et al. Identification of small-animal and primate models for evaluation of vaccine candidates for human metapneumovirus (hMPV) and implications for hMPV vaccine design. J Gen Virol. 2004;85(Pt 6):1655-63.

25. van den Hoogen BG, Herfst S, de Graaf M, Sprong L, van Lavieren R, van Amerongen G, et al. Experimental infection of macaques with human metapneumovirus induces transient protective immunity. J Gen Virol. 2007;88(Pt 4):1251-9.

26. Agapov E, Sumino KC, Gaudreault-Keener M, Storch GA, Holtzman MJ. Genetic variability of human metapneumovirus infection: evidence of a shift in viral genotype without a change in illness. J Infect Dis. 2006;193(3):396-403.

27. Matsuzaki Y, Itagaki T, Abiko C, Aoki Y, Suto A, Mizuta K. Clinical impact of human metapneumovirus genotypes and genotype-specific seroprevalence in Yamagata. Jpn J Med Virol. 2008;80(6):1084-9.

28. Vicente D, Montes M, Cilla G, Perez-Yarza EG, Perez-Trallero E. Differences in clinical severity between genotype $A$ and genotype B human metapneumovirus infection in children. Clin Infect Dis. 2006;42(12):e111-3.

29. Ebihara T, Endo R, Kikuta H, Ishiguro N, Ishiko H, Kobayashi $\mathrm{K}$. Comparison of the seroprevalence of human metapneumovirus and human respiratory syncytial virus. J Med Virol. 2004;72(2):304-6.

30. Leung J, Esper F, Weibel C, Kahn JS. Seroepidemiology of human metapneumovirus (hMPV) on the basis of a novel enzyme-linked immunosorbent assay utilizing hMPV fusion protein expressed in recombinant vesicular stomatitis virus. J Clin Microbiol. 2005;43(3):1213-9.

31. Edwards KM, Zhu Y, Griffin MR, Weinberg GA, Hall CB, Szilagyi PG, et al. Burden of human metapneumovirus infection in young children. N Engl J Med. 2013;368(7):633-43.

32. Williams JV, Edwards KM, Weinberg GA, Griffin MR, Hall $\mathrm{CB}$, Zhu Y, et al. Population-based incidence of human metapneumovirus infection among hospitalized children. J Infect Dis. 2010;201(12):1890-8.
33. Eggleston HA, Gunville CF, Miller JI, Sontag MK, Mourani PM. A comparison of characteristics and outcomes in severe human metapneumovirus and respiratory syncytial virus infections in children treated in an intensive care unit. Pediatr Infect Dis J. 2013 Jun 27.

34. Papenburg J, Hamelin ME, Ouhoummane N, Carbonneau J, Ouakki M, Raymond F, et al. Comparison of risk factors for human metapneumovirus and respiratory syncytial virus disease severity in young children. J Infect Dis. 2012;206(2):178-89.

35. Spaeder MC, Custer JW, Bembea MM, Aganga DO, Song X, Scafidi S. A multicenter outcomes analysis of children with severe viral respiratory infection due to human metapneumovirus. Pediatr Crit Care Med. 2013;14(3):268-72.

36. Hahn A, Wang W, Jaggi P, Dvorchik I, Ramilo O, Koranyi K, et al. Human metapneumovirus infections are associated with severe morbidity in hospitalized children of all ages. Epidemiol Infect. 2013;141(10):2213-23.

37. Pelletier G, Dery P, Abed Y, Boivin G. Respiratory tract reinfections by the new human Metapneumovirus in an immunocompromised child. Emerg Infect Dis. 2002;8(9):976-8.

38. Ali M, Baker JM, Richardson SE, Weitzman S, Allen U, Abla O. Human metapneumovirus (hMPV) infection in children with cancer. J Pediatr Hematol Oncol. 2013;35(6):444-6.

39. - Tollefson SJ, Cox RG, Williams JV. Studies of culture conditions and environmental stability of human metapneumovirus. Virus Res. 2010;151(1):54-9. An important study for development of optimized hygiene protocols avoiding HMPV transmission.

40. Matsuzaki Y, Mizuta K, Takashita E, Okamoto M, Itagaki T, Katsushima F, et al. Comparison of virus isolation using the Vero E6 cell line with real-time RT-PCR assay for the detection of human metapneumovirus. BMC Infect Dis. 2010;10:170.

41. Ebihara T, Endo R, Ma X, Ishiguro N, Kikuta H. Detection of human metapneumovirus antigens in nasopharyngeal secretions by an immunofluorescent-antibody test. J Clin Microbiol. 2005;43(3):1138-41.

42. Fenwick F, Young B, McGuckin R, Robinson MJ, Taha Y, Taylor CE, et al. Diagnosis of human metapneumovirus by immunofluorescence staining with monoclonal antibodies in the North-East of England. J Clin Virol. 2007;40(3):193-6.

43. Manoha C, Bour JB, Pitoiset C, Darniot M, Aho S, Pothier P. Rapid and sensitive detection of metapneumovirus in clinical specimens by indirect fluorescence assay using a monoclonal antibody. J Med Virol. 2008;80(1):154-8.

44. Landry ML, Ferguson D, Cohen S, Peret TC, Erdman DD. Detection of human metapneumovirus in clinical samples by immunofluorescence staining of shell vial centrifugation cultures prepared from three different cell lines. J Clin Microbiol. 2005;43(4):1950-2.

45. Jun KR, Woo YD, Sung H, Kim MN. Detection of human metapneumovirus by direct antigen test and shell vial cultures using immunofluorescent antibody staining. J Virol Methods. 2008;152(1-2):109-11.

46. Percivalle E, Sarasini A, Visai L, Revello MG, Gerna G. Rapid detection of human metapneumovirus strains in nasopharyngeal aspirates and shell vial cultures by monoclonal antibodies. J Clin Microbiol. 2005;43(7):3443-6.

47. Vinh DC, Newby D, Charest H, McDonald J. Evaluation of a commercial direct fluorescent-antibody assay for human metapneumovirus in respiratory specimens. J Clin Microbiol. 2008;46(5):1840-1.

48. Bharaj P, Sullender WM, Kabra SK, Mani K, Cherian J, Tyagi $\mathrm{V}$, et al. Respiratory viral infections detected by multiplex PCR among pediatric patients with lower respiratory tract infections seen at an urban hospital in Delhi from 2005 to 2007. Virol J. 2009;6:89. 
49. Marshall DJ, Reisdorf E, Harms G, Beaty E, Moser MJ, Lee WM, et al. Evaluation of a multiplexed PCR assay for detection of respiratory viral pathogens in a public health laboratory setting. J Clin Microbiol. 2007;45(12):3875-82.

50. Raymond F, Carbonneau J, Boucher N, Robitaille L, Boisvert S, $\mathrm{Wu}$ WK, et al. Comparison of automated microarray detection with real-time PCR assays for detection of respiratory viruses in specimens obtained from children. J Clin Microbiol. 2009;47(3):743-50.

51. Mahony JB. Detection of respiratory viruses by molecular methods. Clin Microbiol Rev. 2008;21(4):716-47.

52. • Balada-Llasat JM, LaRue H, Kelly C, Rigali L, Pancholi P. Evaluation of commercial ResPlex II v2.0, MultiCode-PLx, and xTAG respiratory viral panels for the diagnosis of respiratory viral infections in adults. J Clin Virol. 2011;50(1):42-5. Important study because it heralds the era of multiplexing detection of viral pathogens. As a side observation, this study shows that multiple infections with respiratory viruses are common in hospitalized patients, by the way explaining the high rate of co-pathogens in human bocavirusinfections.

53. Reijans M, Dingemans G, Klaassen CH, Meis JF, Keijdener J, Mulders B, et al. RespiFinder: a new multiparameter test to differentially identify fifteen respiratory viruses. J Clin Microbiol. 2008;46(4):1232-40.

54. Bruijnesteijn van Coppenraet LE, Swanink CM, van Zwet AA, Nijhuis RH, Schirm J, Wallinga JA, et al. Comparison of two commercial molecular assays for simultaneous detection of respiratory viruses in clinical samples using two automatic electrophoresis detection systems. J Virol Methods. 2010;169(1):188-92.

55. Drews SJ, Blair J, Lombos E, DeLima C, Burton L, Mazzulli T, et al. Use of the Seeplex RV Detection kit for surveillance of respiratory viral outbreaks in Toronto, Ontario, Canada. Ann Clin Lab Sci. 2008;38(4):376-9.

56. Pillet S, Lardeux M, Dina J, Grattard F, Verhoeven P, Le Goff J, et al. Comparative evaluation of six commercialized multiplex PCR kits for the diagnosis of respiratory infections. PLoS ONE. 2013;8(8):e72174.

57. Principi N, Esposito S. Paediatric human metapneumovirus infection: Epidemiology, prevention and therapy. J Clin Virol. 2014 Jan 10

58. Nicholson KG, McNally T, Silverman M, Simons P, Stockton JD, Zambon MC. Rates of hospitalisation for influenza, respiratory syncytial virus and human metapneumovirus among infants and young children. Vaccine. 2006;24(1):102-8.

59. Schildgen V, van den Hoogen B, Fouchier R, Tripp RA, Alvarez $\mathrm{R}$, Manoha C, et al. Human Metapneumovirus: lessons learned over the first decade. Clin Microbiol Rev. 2011;24(4):734-54.

60. Garcia-Garcia ML, Calvo C, Perez-Brena P, De Cea JM, Acosta B, Casas I. Prevalence and clinical characteristics of human metapneumovirus infections in hospitalized infants in Spain. Pediatr Pulmonol. 2006;41(9):863-71.

61. Schildgen O, Geikowski T, Glatzel T, Schuster J, Simon A. Frequency of human metapneumovirus in the upper respiratory tract of children with symptoms of an acute otitis media. Eur $\mathbf{J}$ Pediatr. 2005;164(6):400-4001.

62. Williams JV, Tollefson SJ, Nair S, Chonmaitree T. Association of human metapneumovirus with acute otitis media. Int J Pediatr Otorhinolaryngol. 2006;70(7):1189-93.

63. Nokso-Koivisto J, Pyles RB, Miller AL, Patel JA, Loeffelholz $\mathrm{M}$, Chonmaitree T. Viral load and acute otitis media development after human metapneumovirus upper respiratory tract infection. Pediatr Infect Dis J. 2012;31(7):763-6.

64. Miller EK, Gebretsadik T, Carroll KN, Dupont WD, Mohamed YA, Morin LL, et al. Viral etiologies of infant bronchiolitis, croup and upper respiratory illness during 4 consecutive years. Pediatr Infect Dis J. 2013;32(9):950-5.
65. Papenburg J, Boivin G. The distinguishing features of human metapneumovirus and respiratory syncytial virus. Rev Med Virol. 2010;20(4):245-60.

66. Akhras N, Weinberg JB, Newton D. Human metapneumovirus and respiratory syncytial virus: subtle differences but comparable severity. Infect Dis Rep. 2010;2(2):e12.

67. - Wilkesmann A, Schildgen O, Eis-Hubinger AM, Geikowski T, Glatzel T, Lentze MJ, et al. Human metapneumovirus infections cause similar symptoms and clinical severity as respiratory syncytial virus infections. Eur J Pediatr. 2006;165(7):467-75. The first study that systematically shows that RSV and HMPV are clinical indistinguishable.

68. Webster DL, Gardner AH, Dye TJ, Chima RS. Status epilepticus: a possible association with human metapneumovirus infection. Pediatrics. 2014 Feb 10.

69. Schildgen O, Muller A, Simon A. Human metapneumovirus and encephalitis. J Clin Virol. 2007;38(4):366.

70. Arnold JC, Singh KK, Milder E, Spector SA, Sawyer MH, Gavali S, et al. Human metapneumovirus associated with central nervous system infection in children. Pediatr Infect Dis J. 2009;28(12):1057-60.

71. Williams JV, Harris PA, Tollefson SJ, Halburnt-Rush LL, Pingsterhaus JM, Edwards KM, et al. Human metapneumovirus and lower respiratory tract disease in otherwise healthy infants and children. N Engl J Med. 2004;350(5):443-50.

72. Klein MI, Coviello S, Bauer G, Benitez A, Serra ME, Schiatti MP, et al. The impact of infection with human metapneumovirus and other respiratory viruses in young infants and children at high risk for severe pulmonary disease. J Infect Dis. 2006;193(11):1544-51.

73. Ulloa-Gutierrez R, Skippen P, Synnes A, Seear M, Bastien N, Li $\mathrm{Y}$, et al. Life-threatening human metapneumovirus pneumonia requiring extracorporeal membrane oxygenation in a preterm infant. Pediatrics. 2004;114(4):e517-9.

74. Eggleston HA, Gunville CF, Miller JI, Sontag MK, Mourani PM. A comparison of characteristics and outcomes in severe human metapneumovirus and respiratory syncytial virus infections in children treated in an intensive care unit. Pediatr Infect Dis J. 2013 Jun 27 (in press).

75. Simon A, Schildgen O, Schuster F. Viral infections in children with cancer. Arch Dis Child. 2008;93(10):880-9.

76. Srinivasan A, Gu Z, Smith T, Morgenstern M, Sunkara A, Kang G, et al. Prospective detection of respiratory pathogens in symptomatic children with cancer. Pediatr Infect Dis J. 2013;32(3):e99-104.

77. Williams JV, Crowe JE Jr, Enriquez R, Minton P, Peebles RS Jr, Hamilton RG, et al. Human metapneumovirus infection plays an etiologic role in acute asthma exacerbations requiring hospitalization in adults. J Infect Dis. 2005;192(7):1149-53.

78. Amin NM, El Basha NR, El Rifai NM, El Baz MS, Draz IH, El Kholy AA, et al. Viral causes of acute respiratory infection among Egyptian children hospitalized with severe acute asthma exacerbation. J Egypt Public Health Assoc. 2013;88(1):52-6.

79. Garcia DF, Hiatt PW, Jewell A, Schoonover SL, Cron SG, Riggs $\mathrm{M}$, et al. Human metapneumovirus and respiratory syncytial virus infections in older children with cystic fibrosis. Pediatr Pulmonol. 2007;42(1):66-74.

80. Flight WG, Bright-Thomas RJ, Tilston P, Mutton KJ, Guiver M, Morris J, et al. Incidence and clinical impact of respiratory viruses in adults with cystic fibrosis. Thorax. 2014;69(3):247-53.

81. Martinello RA, Esper F, Weibel C, Ferguson D, Landry ML, Kahn JS. Human metapneumovirus and exacerbations of chronic obstructive pulmonary disease. J Infect. 2006;53(4):248-54.

82. Simon A, Prusseit J, Muller A. Respiratory syncytial virus infection in children with neuromuscular impairment. Open Microbiol J. 2011;5:155-8.

83. Muller A, Kupfer B, Vehreschild J, Cornely O, Kaiser R, Seifert $\mathrm{H}$, et al. Fatal pneumonia associated with human 
metapneumovirus (HMPV) in a patient with myeloid leukemia and adenocarcinoma in the lung. Eur $\mathrm{J}$ Med Res. 2007;12(4):183-4.

84. Egli A, Bucher C, Dumoulin A, Stern M, Buser A, Bubendorf L, et al. Human metapneumovirus infection after allogeneic hematopoietic stem cell transplantation. Infection. 2012;40(6):677-84.

85. Choi JH, Choi EH, Kang HJ, Park KD, Park SS, Shin HY, et al. Respiratory viral infections after hematopoietic stem cell transplantation in children. J Korean Med Sci. 2013;28(1):36-41.

86. Dokos C, Masjosthusmann K, Rellensmann G, Werner C, Schuler-Luttmann S, Muller KM, et al. Fatal human metapneumovirus infection following allogeneic hematopoietic stem cell transplantation. Transpl Infect Dis. 2013;15(3):E97-101.

87. Renaud C, Xie H, Seo S, Kuypers J, Cent A, Corey L, et al. Mortality rates of human metapneumovirus and respiratory syncytial virus lower respiratory tract infections in hematopoietic cell transplantation recipients. Biol Blood Marrow Transpl. 2013;19(8):1220-6.

88. Gupta A, Bembea M, Brown A, Robertson C, Romer L, Cohn $\mathrm{RD}$. Respiratory failure secondary to human metapneumovirus requiring extracorporeal membrane oxygenation in a 32-monthold child. Case Rep Pediatr. 2012;2012:268074.

89. Paget SP, Andresen DN, Kesson AM, Egan JR. Comparison of human metapneumovirus and respiratory syncytial virus in children admitted to a paediatric intensive care unit. J Paediatr Child Health. 2011;47(10):737-41.

90. Centers for Disease Control and Prevention. (CDC). Outbreaks of human metapneumovirus in two skilled nursing facilities West Virginia and Idaho, 2011-2012. MMWR Morb Mortal Wkly Rep. 2013;62(46):909-13.

91. Liao RS, Appelgate DM, Pelz RK. An outbreak of severe respiratory tract infection due to human metapneumovirus in a long-term care facility for the elderly in Oregon. J Clin Virol. 2012;53(2):171-3.

92. Te Wierik MJ, Nguyen DT, Beersma MF, Thijsen SF, Heemstra KA. An outbreak of severe respiratory tract infection caused by human metapneumovirus in a residential care facility for elderly in Utrecht, the Netherlands, January to March 2010. Euro Surveill. 2012;17(13).

93. - Martin ET, Kuypers J, Wald A, Englund JA. Multiple versus single virus respiratory infections: viral load and clinical disease severity in hospitalized children. Influenza Other Respir Viruses. 2012;6(1):71-7. An important study focussing on multiple infections.

94. Ricart S, Garcia-Garcia JJ, Anton A, Pumarola T, Pons M, MunozAlmagro C, et al. Analysis of human metapneumovirus and human bocavirus viral load. Pediatr Infect Dis J. 2013;32(9):1032-4.

95. Utokaparch S, Marchant D, Gosselink JV, McDonough JE, Thomas EE, Hogg JC, et al. The relationship between respiratory viral loads and diagnosis in children presenting to a pediatric hospital emergency department. Pediatr Infect Dis J. 2011;30(2):e18-23.

96. Franz A, Adams O, Willems R, Bonzel L, Neuhausen N, Schweizer-Krantz S, et al. Correlation of viral load of respiratory pathogens and co-infections with disease severity in children hospitalized for lower respiratory tract infection. J Clin Virol. 2010;48(4):239-45.

97. Nicolai A, Ferrara M, Schiavariello C, Gentile F, Grande ME, Alessandroni C, et al. Viral bronchiolitis in children: a common condition with few therapeutic options. Early Hum Dev. 2013;89(Suppl 3):S7-11.

98. Simon A, Schildgen O. Antimicrobial therapy in childhood asthma and wheezing. Treat Respir Med. 2006;5(4):255-69.

99. Keith T, Saxena S, Murray J, Sharland M. Risk-benefit analysis of restricting antimicrobial prescribing in children: what do we really know? Curr Opin Infect Dis. 2010;23(3):242-8.
100. Wyde PR, Chetty SN, Jewell AM, Boivin G, Piedra PA. Comparison of the inhibition of human metapneumovirus and respiratory syncytial virus by ribavirin and immune serum globulin in vitro. Antiviral Res. 2003;60(1):51-9.

101. Hamelin ME, Prince GA, Boivin G. Effect of ribavirin and glucocorticoid treatment in a mouse model of human metapneumovirus infection. Antimicrob Agents Chemother. 2006;50(2):774-7.

102. Kitanovski L, Kopriva S, Pokorn M, Dolnicar MB, Rajic V, Stefanovic M, et al. Treatment of severe human metapneumovirus (hMPV) pneumonia in an immunocompromised child with oral ribavirin and IVIG. J Pediatr Hematol Oncol. 2013;35(7):e311-3.

103. Shachor-Meyouhas Y, Ben-Barak A, Kassis I. Treatment with oral ribavirin and IVIG of severe human metapneumovirus pneumonia (HMPV) in immune compromised child. Pediatr Blood Cancer. 2011;57(2):350-1.

104. Raza K, Ismailjee SB, Crespo M, Studer SM, Sanghavi S, Paterson DL, et al. Successful outcome of human metapneumovirus (hMPV) pneumonia in a lung transplant recipient treated with intravenous ribavirin. J Heart Lung Transpl. 2007;26(8):862-4.

105. Park SY, Baek S, Lee SO, Choi SH, Kim YS, Woo JH, et al. Efficacy of oral ribavirin in hematologic disease patients with paramyxovirus infection: analytic strategy using propensity scores. Antimicrob Agents Chemother. 2013;57(2):983-9.

106. Bonney D, Razali H, Turner A, Will A. Successful treatment of human metapneumovirus pneumonia using combination therapy with intravenous ribavirin and immune globulin. Br J Haematol. 2009;145(5):667-9.

107. Principi N, Esposito S. Paediatric human metapneumovirus infection: epidemiology, prevention and therapy. J Clin Virol. 2014;59(3):141-7.

108. Deffrasnes C, Hamelin ME, Prince GA, Boivin G. Identification and evaluation of a highly effective fusion inhibitor for human metapneumovirus. Antimicrob Agents Chemother. 2008;52(1):279-87.

109. Darniot M, Schildgen V, Schildgen O, Sproat B, Kleines M, Ditt $\mathrm{V}$, et al. RNA interference in vitro and in vivo using DsiRNA targeting the nucleocapsid N mRNA of human metapneumovirus. Antiviral Res. 2012;93(3):364-73.

110. Deffrasnes C, Cavanagh MH, Goyette N, Cui K, Ge Q, Seth S, et al. Inhibition of human metapneumovirus replication by small interfering RNA. Antivir Ther. 2008;13(6):821-32.

111. Williams JV, Chen Z, Cseke G, Wright DW, Keefer CJ, Tollefson SJ, et al. A recombinant human monoclonal antibody to human metapneumovirus fusion protein that neutralizes virus in vitro and is effective therapeutically in vivo. $\mathrm{J}$ Virol. 2007;81(15):8315-24.

112. Ulbrandt ND, Ji H, Patel NK, Riggs JM, Brewah YA, Ready S, et al. Isolation and characterization of monoclonal antibodies which neutralize human metapneumovirus in vitro and in vivo. J Virol. 2006;80(16):7799-806.

113. Hamelin ME, Couture C, Sackett M, Kiener P, Suzich J, Ulbrandt N, et al. The prophylactic administration of a monoclonal antibody against human metapneumovirus attenuates viral disease and airways hyperresponsiveness in mice. Antivir Ther. 2008;13(1):39-46.

114. Hamelin ME, Gagnon C, Prince GA, Kiener P, Suzich J, Ulbrandt $\mathrm{N}$, et al. Prophylactic and therapeutic benefits of a monoclonal antibody against the fusion protein of human metapneumovirus in a mouse model. Antivir Res. 2010;88(1):31-7.

115. Corti D, Bianchi S, Vanzetta F, Minola A, Perez L, Agatic G, et al. Cross-neutralization of four paramyxoviruses by a human monoclonal antibody. Nature. 2013;501(7467):439-43.

116. Liu P, Shu Z, Qin X, Dou Y, Zhao Y, Zhao X. A live attenuated human metapneumovirus vaccine strain provides complete protection against homologous viral infection and cross-protection against heterologous viral infection in BALB/c mice. Clin Vaccin Immunol. 2013;20(8):1246-54. 
117. Levy C, Aerts L, Hamelin ME, Granier C, Szecsi J, Lavillette D, et al. Virus-like particle vaccine induces cross-protection against human metapneumovirus infections in mice. Vaccine. 2013;31(25):2778-85.

118. Cseke G, Wright DW, Tollefson SJ, Johnson JE, Crowe JE Jr, Williams JV. Human metapneumovirus fusion protein vaccines that are immunogenic and protective in cotton rats. J Virol. 2007;81(2):698-707.

119. Herfst S, Fouchier RA. Vaccination approaches to combat human metapneumovirus lower respiratory tract infections. J Clin Virol. 2008;41(1):49-52.

120. Herfst S, Schrauwen EJ, de Graaf M, van Amerongen G, van den Hoogen BG, de Swart RL, et al. Immunogenicity and efficacy of two candidate human metapneumovirus vaccines in cynomolgus macaques. Vaccine. 2008;26(33):4224-30.

121. Hirsch HH, Martino R, Ward KN, Boeckh M, Einsele H, Ljungman P. Fourth European Conference on Infections in Leukaemia (ECIL-4): guidelines for diagnosis and treatment of human respiratory syncytial virus, parainfluenza virus, metapneumovirus, rhinovirus, and coronavirus. Clin Infect Dis. 2013;56(2):258-66.

122. Schildgen O, Glatzel T, Geikowski T, Scheibner B, Matz B, Bindl L, et al. Human metapneumovirus RNA in encephalitis patient. Emerg Infect Dis. 2005;11(3):467-70.

123. Sanchez Fernandez I, Rebollo Polo M, Munoz-Almagro C, Monfort Carretero L, Fernandez Urena S, Rueda Munoz A, et al. Human Metapneumovirus in the cerebrospinal fluid of a patient with acute encephalitis. Arch Neurol. 2012;69(5):649-52.

124. Webster DL, Gardner AH, Dye TJ, Chima RS. Status epilepticus: a possible association with human metapneumovirus infection. Pediatrics. 2014;133(3):e747-50.
125. Schildgen O, Simon A, Williams J. Animal models for human metapneumovirus (HMPV) infections. Vet Res. 2007;38(1):117-26.

126. Alvarez R, Harrod KS, Shieh WJ, Zaki S, Tripp RA. Human metapneumovirus persists in BALB/c mice despite the presence of neutralizing antibodies. J Virol. 2004;78(24):14003-11.

127. Alvarez R, Tripp RA. The immune response to human metapneumovirus is associated with aberrant immunity and impaired virus clearance in BALB/c mice. J Virol. 2005;79(10):5971-8.

128. Spetch L, Bowlin TL, Casola A. Effect of NMSO3 treatment in a murine model of human metapneumovirus infection. J Gen Virol. 2008;89(Pt 11):2709-12.

129. Darniot M, Pitoiset C, Petrella T, Aho S, Pothier P, Manoha C. Age-associated aggravation of clinical disease after primary metapneumovirus infection of $\mathrm{BALB} / \mathrm{c}$ mice. $\mathrm{J}$ Virol. 2009;83(7):3323-32.

130. Wyde PR, Moylett EH, Chetty SN, Jewell A, Bowlin TL, Piedra PA. Comparison of the inhibition of human metapneumovirus and respiratory syncytial virus by NMSO3 in tissue culture assays. Antivir Res. 2004;63(1):51-9.

131. Mendes G, Soares AR, Sigiliano L, Machado F, Kaiser C, Romeiro N, et al. In vitro anti-HMPV activity of meroditerpenoids from marine alga Stypopodium zonale (Dictyotales). Molecules. 2011;16(10):8437-50.

132. Preston FM, Straub CP, Ramirez R, Mahalingam S, Spann KM. siRNA against the $\mathrm{G}$ gene of human metapneumovirus. Virol $\mathrm{J}$. 2012;9:105. 